\title{
Patrones de consumo de alcohol y problemas asociados en Brasil
}

\section{Drinking patterns and associated problems in Brazil}

\author{
Raul Caetano*; Clarice Madruga**; Ilana Pinsky **; Ronaldo Laranjeira** \\ * University of Texas School of Public Health, Dallas Regional Campus, USA; **Alcohol and Drugs Research Unit (Unidade de \\ Pesquisa em Álcool e Outras Drogas; UNIAD), Department of Psychiatry, Universidade Federal de São Paulo (UNIFESP), São \\ Paulo, SP, Brasil.
}

\section{Resumen}

Este artículo describe los patrones de consumo de alcohol y los problemas asociados en Brasil. Los datos provienen de una muestra aleatoria multicluster de 2.346 brasileños de 18 y más años de edad. La encuesta fue llevada a cabo en el período 2005-2006 y tuvo una tasa de respuesta del $66,4 \%$. Alrededor del $35 \%$ de los hombres y $59 \%$ de las mujeres no habían bebido durante los últimos 12 meses, mientras que el 39\% de los hombres y el 13\% de las mujeres consumían alcohol al menos una vez a la semana. Además, el $38 \%$ de los hombres y el $17 \%$ de las mujeres consumían "por lo general" 5 o más bebidas, y el $40 \%$ de los hombres y el $18 \%$ de las mujeres informaron de un consumo intensivo (binge drinking) en los últimos 12 meses. La prevalencia de los trastornos por consumo de alcohol (abuso y/o dependencia según el DSM-IV) fue del $19 \%$ para los hombres y $4 \%$ para las mujeres. A pesar de que la abstinencia es en Brasil relativamente alta, el consumo excesivo de alcohol es frecuente y, por lo tanto, los problemas de alcohol y los trastornos por consumo de alcohol también lo son.

Palabras clave: Brasil, encuesta, epidemiología, consumo, trastornos por consumo de alcohol.

\begin{abstract}
This paper describes patterns of alcohol consumption and associated problems in Brazil. Data came from a multicluster random sample of 2,346 Brazilians 18 years of age and older. The survey was conducted in 2005-2006 and had a response rate of $66.4 \%$. About $35 \%$ of the men and $59 \%$ of the women did not drink in the past 12 months, while $39 \%$ of the men and $13 \%$ of the women consumed alcohol at least once a week. Further, $38 \%$ of the men and $17 \%$ of the women consumed 5 or more drinks "usually", and $40 \%$ of the men and $18 \%$ of the women reported binge drinking in the past 12 months. The prevalence of alcohol use disorders (DSM-4 abuse and/or dependence) was 19\% among men and 4\% among women. Although abstinence in Brazil is relatively high, binge drinking is frequent and, thus, alcohol problems and alcohol use disorders are also frequent.
\end{abstract}

Key words: Brazil, survey, epidemiology, drinking, alcohol use disorders. 
$\mathrm{T}$ he objective of this paper is to offer a broad characterization of patterns of alcohol consumption and associated problems in Brazil, including frequency of consumption, usual quantity consumed, binge drinking, and the prevalence of alcohol use disorders. The first section of the paper describes the present social and economic context in Brazil, discussing also population-level alcohol consumption indicators such as per capita consumption and the burden of disease attributed to alcohol, existing alcohol control policies, and treatment. Following this, there is a brief discussion of the existing alcohol epidemiological literature, focusing on large population studies of adults and adolescents. The third part of the paper reviews findings from Laranjeira, Pinsky, Sanches, Zaleski, and Caetano (2010) and presents data from a 2006 national survey of alcohol consumption in the Brazilian population. This is followed by a discussion of these findings.

\section{The Brazilian context}

Brazil is the largest country in Latin America, with a national territory of $8.511 .925 \mathrm{Km} 2$ and a population of 190 million people. In 2012, it was the 7th largest economy in the world by size (http://www.imf.org/external/pubs/ft/ weo/2012/02/weodata/index.aspx, accessed on March 18, 2013), and it is 1 of 4 "BRIC" countries (the others are Russia, India, and China) identified by the alcohol industry with considerable potential for market growth. Recorded annual alcohol consumption in the Brazilian population is 6 liters per capita for individuals 15 years of age and older (Caetano \& Laranjeira, 2006; Room et al., 2002). However, because abstention in Brazil is high, about $35 \%$ of the men and $59 \%$ of the women abstain from drinking (past 12 months) (Laranjeira et al., 2010), per capita consumption among drinkers is likely to exceed 6 liters. There also is a high prevalence of alcohol use disorders $(9.6 \%)$. We will expand on these facts below.

The alcohol-attributable burden of disease in the 2 regions of the Americas that include most Latin American countries (World Health Organization's [WHO] Americas 'B' and 'D') varies between $8.6 \%$ and $17.3 \%$ for men and $2.2 \%$ and $4.1 \%$ for women (Babor et al., 2003). As a comparison, the world burden for men is $6.5 \%$ and for women it is $1.3 \%$. Recently, Caetano and Laranjeira (2006) identified a number of factors that presently contribute to increased per capita consumption in Brazil, such as a youthful population, lack of alcohol control policies regulating alcohol availability, targeting by the alcohol industry for market development, weak public health infrastructure, and governmental policies that support economic growth and welcome the alcohol industry. Brazil received the lowest score among 25 countries in the Americas on the estimated impact of alcohol-policy strategies implemented in the country (Babor \& Caetano, 2005).
The good news is that concern for the health problems associated with alcohol is growing. For instance, in 2008, Brazil enacted a new lower blood alcohol concentration (BAC) level, which makes it illegal to drive with a BAC above .02 (http://www.planalto.gov.br/ccivil_03/_Ato20072010/2008/Lei/L11705.htm; accessed on June 8, 2010). Those caught driving illegally will pay a fine of approximately 560 U.S. dollars and will lose their driving license for 12 months. A BAC level above .06 will result in immediate arrest, jail time ranging from 6 months to 3 years, plus fines ranging from 175 to 700 U.S. dollars. Unfortunately, enforcement of this law is bound to be uneven and will mostly happen in the larger metropolitan areas of the country where police resources necessary for enforcement are located.

Substance use treatment in Brazil, including treatment for alcohol abuse and dependence, is conducted in various settings. The Brazilian psychiatric system has been through structural reforms since 2002 (Ministério da Saúde, 2003). A network of facilities, the Psycho-Social Care Center for Alcohol and Drugs (CAPS-AD), has been implemented and is in constant change (Ministério da Saúde, 2002). Brazilians can also count on other public services for alcohol dependents such as Alcoholics Anonymous, religious or non-profitable organizations running "detox farms", and also hospital-based day care and inpatient treatments. However, access to these services by the population is still far from satisfactory.

\section{Brief review of alcohol epidemiology in Brazil}

Brazil has only recently started to develop comprehensive population studies of the pattern of alcohol consumption among the adult population. Most published articles concentrate on harmful drinking (identified variously as heavy consumption, harmful use, high-risk consumption) and on the associated socio-economic factors. Because of variations in sampling design and different definitions of heavy alcohol consumption, the results of different surveys undertaken in Brazil are not always comparable (Galduróz \& Carlini, 2007; Kerr-Corrêa et al., 2008; Laranjeira et al., 2010; Wolle et al., 2011). Nonetheless, several studies demonstrate a high prevalence of harmful drinking, especially among men. One of the first studies was performed in the southern city of Porto Alegre and used the instrument CAGE6 as an indicator of alcohol dependence. Rates of $9.3 \%$ for dependence and $15.5 \%$ for heavy use were found, as well as a positive association with male gender, older age, low salary and schooling, and non-white ethnicity (Moreira et al., 1996). Another study, also performed in the south of the country, has defined heavy drinking as consumption above $30 \mathrm{~g}$ of daily alcohol (Capriglione, Monteiro, \& Masur, 1985). In spite of the variation in the definition of heavy drinking, the rate was similar to that of the previous study: $14.3 \%$ for heavy 
use, with a profound distinction between men and women, $29.2 \%$ and $3.7 \%$ respectively.

In the State of Bahia, a comprehensive study performed of 2,302 adults examined the association of high-risk consumption (defined as related to frequent states of drunkenness) with sociodemographic variables. As opposed to studies in the southern states, high-risk use showed a positive relationship with higher educational level and social class. Another interesting observation is that in a population with just less than $50 \%$ abstinence, $7 \%$ (13\% for men) showed high-risk consumption. A multicentre study focused on psychiatric diagnoses conducted in the cities of São Paulo, Brasília, and Porto Alegre using strict criteria based on the WHO's alcohol dependence classification, has found consistent rates of nearly $8 \%$ of alcohol dependence in those major cities. Other comprehensive surveys of the general population have been undertaken both in the city (Silveira, Wang, Andrade, \& Andrade, 2007) and in the state of São Paulo (Galduróz, Noto, Nappo, \& Carlini, 2003a, 2003b), including a recent study showing that both men and women had similar patterns of drinking (Kerr-Corrêa, Igamib, Hirocea, \& Tucci, 2007).

\section{The 2006 Brazilian National Survey of Alcohol Consumption patterns}

This survey was conducted by the Research Unit on Alcohol and Drugs (UNIAD) of the Universidade Federal de São Paulo (Unifesp) from November 2005 up to April 2006. The survey covered 143 Brazilian cities and, within them, a total of 325 census sectors, including those situated in rural areas. The interviews were carried out in the home.

The sample was multistage probabilistic of the household population in Brazil. There were a total of 2,346 interviews with adults aged 18 years or older, representing a profile of the Brazilian population, excluding native Brazilians who live on Indian reservations and also populations who live in communities, such as prisons. Trained interviewers carried out a face-to-face interview in the selected households with a mean duration of 53 minutes. The response rate was $66.4 \%$. The survey's instrument was a version of the questionnaire used in the Hispanic Americans Baseline Alcohol Survey (HABLAS) (Caetano, Ramisetty-Mikler, \& Rodriguez, 2009). The questionnaire was translated by the survey's coordinators and underwent a process of adaptation to the socio-cultural reality of the Brazilian population. The study was approved by a human subjects/internal review board process at the university (code: CEP 1672/04). All respondents signed an informed consent form and were assured of the confidential nature of the study before the interview. They were told that this was a national pioneer study and that their participation was important to guide future government public policies.
The survey questionnaire coverage of sociodemographic, alcohol consumption, and alcohol problems data was quite comprehensive. Respondents were asked for the frequency and usual quantity of drinking and binge drinking. Alcohol problems were covered with 28 questions on social, family-related, work-related, legal, and physical health problems. Alcohol abuse and dependence were identified with use of the Composite International Diagnostic Interview (CIDI), which follows DSM-IV diagnostic criteria.

Tables 1, 2, and 3 below are from Laranjeira et al. (2010). About a tenth of the men but only $2 \%$ of the women reported very frequent (every day or almost every day) consumption of alcohol beverages (Table 1). A third of the men and a tenth of the women reported frequent drinking (1 to 4 times a week). Occasional consumption ( 1 to 3 times a month) was reported by a fifth of the men and $16 \%$ of the women. About a tenth of the men and women drank only rarely (less than once a month). Finally, a little over a third of the men and about 3 fifths of the women were abstinent in the past 12 months. Drinking was more frequent in the Southern region of the country, an area of Brazil where wine production is concentrated. Rural versus urban differences were not statistically significant.

These results vary with age, region of the country, and urbanization. For instance, abstinence was higher among those who were older, in the Northern region, and in rural areas. There were more frequent and occasional drinkers among those who were younger and there were more frequent or very frequent drinkers in the Southern region of the country. Regarding usual quantity of drinking, men and those who were younger reported higher usual quantities than women and those who were older (Table 2). Differences by region and urbanization level were not statistically significant. Binge drinking in the past 12 months was reported by a high proportion of men $(40 \%)$ and women $(18 \%)$. The same was true for those who were younger compared to those who were older. The Southern part of the country and urban areas had a higher proportion of binge drinkers, but these results were not statistically significant. Other analyses of binge drinking (Castro et al., 2012) showed that binging in the Brazilian population was more common among participants who were male (odds ratio (OR) 2.9; 95\% CI 2.3-3.6), single (OR 1.5; $95 \%$ CI 1.1-2.1), or had higher family income (OR 2.3; 95\% CI 1.3-3.8). Individuals between 18 and 44 years of age were 4 times more likely to engage in binge drinking than adolescents (OR 4.7; 95\% CI 3.3-6.8). Evangelicals/Protestants were less likely to engage in binge drinking (OR 0.7; 95\% CI 0.2-0.5).

One quarter of the sample (including non-drinkers) reported at least one problem related to alcohol consumption (Table 3). Men, those who were younger, and those in urban areas had a higher prevalence of having at least one alcohol problem. Differences in problem rate by region of the country were not significant. Alcohol use disorders (abuse 
and dependence) were present in $11 \%$ of the sample and were also more prevalent among men and among younger respondents. Differences across regions of Brazil and urban versus rural areas were not statistically significant.

Table 1

Frequency of consumption of alcoholic beverages in the prior twelve months and its relationship with socio-demographic variables (\%)

\begin{tabular}{|c|c|c|c|c|c|c|c|c|c|c|c|c|}
\hline \multicolumn{2}{|c|}{ Demographic } & \multicolumn{2}{|c|}{ Very frequent } & \multicolumn{2}{|c|}{ Frequent } & \multicolumn{2}{|c|}{ Occasional } & \multicolumn{2}{|c|}{ Rarely } & \multicolumn{2}{|c|}{ Abstinent } & \multirow[t]{2}{*}{ p-value } \\
\hline & & $(\%)$ & (SD) & $(\%)$ & (SD) & {$[\%]$} & (SD) & $(\%)$ & (SD) & $(\%)$ & (SD) & \\
\hline \multirow[t]{2}{*}{ Gender } & Male & $11 \%$ & $1.2 \%$ & $28 \%$ & $2.0 \%$ & $19 \%$ & $1.5 \%$ & $8 \%$ & $1.0 \%$ & $35 \%$ & $1.9 \%$ & $<0.001$ \\
\hline & Female & $2 \%$ & $0.4 \%$ & $11 \%$ & $1.0 \%$ & $16 \%$ & $1.3 \%$ & $12 \%$ & $1.1 \%$ & $59 \%$ & $1.7 \%$ & \\
\hline \multirow[t]{4}{*}{ Age } & $18-24$ years & $4 \%$ & $1.2 \%$ & $22 \%$ & $2.5 \%$ & $24 \%$ & $2.6 \%$ & $13 \%$ & $2.1 \%$ & $38 \%$ & $3.2 \%$ & $<0.001$ \\
\hline & $35-44$ years & $7 \%$ & $1.7 \%$ & $23 \%$ & $2.5 \%$ & $18 \%$ & $2.3 \%$ & $8 \%$ & $1.3 \%$ & $44 \%$ & $2.9 \%$ & \\
\hline & $45-59$ years & $8 \%$ & $1.3 \%$ & $16 \%$ & $2.1 \%$ & $14 \%$ & $1.9 \%$ & $9 \%$ & $1.6 \%$ & $54 \%$ & $2.8 \%$ & \\
\hline & 60 years or above & $7 \%$ & $1.6 \%$ & $8 \%$ & $1.7 \%$ & $10 \%$ & $2.0 \%$ & $8 \%$ & $1.7 \%$ & $68 \%$ & $2.9 \%$ & \\
\hline \multirow[t]{4}{*}{ Region } & Northern & $4 \%$ & $1.9 \%$ & $10 \%$ & $3.3 \%$ & $21 \%$ & $3.9 \%$ & $11 \%$ & $1.8 \%$ & $54 \%$ & $5.4 \%$ & 0.017 \\
\hline & Northeastern & $3 \%$ & $1.1 \%$ & $21 \%$ & $2.1 \%$ & $16 \%$ & $1.6 \%$ & $10 \%$ & $1.4 \%$ & $50 \%$ & $2.5 \%$ & \\
\hline & Southeastern & $6 \%$ & $0.8 \%$ & $18 \%$ & $1.6 \%$ & $17 \%$ & $1.5 \%$ & $10 \%$ & $1.4 \%$ & $50 \%$ & $2.0 \%$ & \\
\hline & Southern & $11 \%$ & $2.2 \%$ & $25 \%$ & $3.8 \%$ & $19 \%$ & $3.0 \%$ & $10 \%$ & $2.1 \%$ & $35 \%$ & $4.5 \%$ & \\
\hline \multirow[t]{2}{*}{ Rural } & Urban & $6 \%$ & $0.7 \%$ & $20 \%$ & $1.3 \%$ & $17 \%$ & $1.1 \%$ & $10 \%$ & $0.9 \%$ & $47 \%$ & $1.4 \%$ & 0.079 \\
\hline & Rural & $7 \%$ & $1.7 \%$ & $13 \%$ & $2.0 \%$ & $17 \%$ & $2.3 \%$ & $11 \%$ & $2.0 \%$ & $54 \%$ & $3.6 \%$ & \\
\hline
\end{tabular}

Note: Table source is Laranjeira, Ronaldo, Pinsky, Ilana, Sanches, Marcos, Zaleski, Marcos, \& Caetano, Raul. (2010). Padrão de uso de álcool em brasileiros adultos / Alcohol use patterns among Brazilian adults. Revista Brasileira de Psiquiatria, 32(3), 231-241.

Table 2

Usual quantity consumed and binge drinking and their relationship with socio-demographic variables

\begin{tabular}{|c|c|c|c|c|c|c|c|c|c|c|c|c|c|}
\hline \multicolumn{2}{|c|}{ Demographic } & \multicolumn{9}{|c|}{ Usual quantity } & \multicolumn{3}{|c|}{ Binge drinking } \\
\hline & & \multicolumn{2}{|c|}{12 or more units } & \multicolumn{2}{|c|}{ From 5 to 11 units } & \multicolumn{2}{|c|}{ From 3 to 4 units } & \multicolumn{2}{|c|}{ Up to 2 units } & \multirow[t]{2}{*}{ p-value } & \multirow{2}{*}{$\begin{array}{c}\text { No } \\
(\%)\end{array}$} & \multirow{2}{*}{$\begin{array}{l}\text { Yes } \\
(\%)\end{array}$} & \multirow{2}{*}{$\frac{\text { p-value }}{\text { (SD) }}$} \\
\hline & & $(\%)$ & (SD) & $(\%)$ & (SD) & $(\%)$ & (SD) & $(\%)$ & (SD) & & & & \\
\hline \multirow[t]{2}{*}{ Gender } & Male & $11 \%$ & $2.3 \%$ & $27 \%$ & $2.3 \%$ & $25 \%$ & $2.0 \%$ & $38 \%$ & $2.7 \%$ & $\leftarrow 0.001$ & $60 \%$ & $40 \%$ & $<0.001$ \\
\hline & Female & $3 \%$ & $0.9 \%$ & $14 \%$ & $1.9 \%$ & $19 \%$ & $2.0 \%$ & $63 \%$ & $2.7 \%$ & & $82 \%$ & $18 \%$ & \\
\hline \multirow[t]{5}{*}{ Age } & $18-24$ years & $9 \%$ & $2.8 \%$ & $24 \%$ & $3.4 \%$ & $30 \%$ & $3.5 \%$ & $37 \%$ & $4.2 \%$ & $\leftarrow 0.001$ & $60 \%$ & $40 \%$ & $<0.001$ \\
\hline & $25-34$ years & $9 \%$ & $1.9 \%$ & $26 \%$ & $2.9 \%$ & $20 \%$ & $2.6 \%$ & $45 \%$ & $3.2 \%$ & & $63 \%$ & $37 \%$ & \\
\hline & $35-44$ years & $8 \%$ & $2.2 \%$ & $24 \%$ & $3.4 \%$ & $20 \%$ & $3.0 \%$ & $48 \%$ & $3.8 \%$ & & $72 \%$ & $28 \%$ & \\
\hline & $45-59$ years & $4 \%$ & $1.4 \%$ & $15 \%$ & $2.5 \%$ & $24 \%$ & $3.2 \%$ & $57 \%$ & $3.6 \%$ & & $80 \%$ & $20 \%$ & \\
\hline & $\begin{array}{l}60 \text { years or } \\
\text { above }\end{array}$ & $5 \%$ & $2.4 \%$ & $12 \%$ & $3.7 \%$ & $12 \%$ & $3.6 \%$ & $70 \%$ & $4.9 \%$ & & $90 \%$ & $10 \%$ & \\
\hline \multirow[t]{5}{*}{ Region } & Northern & $9 \%$ & $3.0 \%$ & $24 \%$ & $8.7 \%$ & $21 \%$ & $5.3 \%$ & $45 \%$ & $10.6 \%$ & 0.003 & $79 \%$ & $21 \%$ & 0.106 \\
\hline & Center-Western & $7 \%$ & $3.5 \%$ & $31 \%$ & $6.5 \%$ & $25 \%$ & $3.0 \%$ & $37 \%$ & $5.8 \%$ & & $73 \%$ & $27 \%$ & \\
\hline & Northeastern & $13 \%$ & $4.7 \%$ & $25 \%$ & $3.9 \%$ & $25 \%$ & $3.2 \%$ & $36 \%$ & $4.2 \%$ & & $70 \%$ & $30 \%$ & \\
\hline & Southeastern & $6 \%$ & $1.4 \%$ & $20 \%$ & $2.1 \%$ & $25 \%$ & $2.2 \%$ & $50 \%$ & $2.9 \%$ & & $74 \%$ & $26 \%$ & \\
\hline & Southern & $4 \%$ & $1.9 \%$ & $18 \%$ & $3.7 \%$ & $12 \%$ & $2.3 \%$ & $66 \%$ & $5.4 \%$ & & $64 \%$ & $36 \%$ & \\
\hline \multirow[t]{2}{*}{ Rural } & Urban & $8 \%$ & $1.6 \%$ & $21 \%$ & $1.7 \%$ & $22 \%$ & $1.4 \%$ & $48 \%$ & $2.3 \%$ & 0.281 & $71 \%$ & $29 \%$ & 0.287 \\
\hline & Rural & $3 \%$ & $1.5 \%$ & $26 \%$ & $5.2 \%$ & $23 \%$ & $3.7 \%$ & $49 \%$ & $5.5 \%$ & & $75 \%$ & $25 \%$ & \\
\hline
\end{tabular}

Note: Table source is Laranjeira, Ronaldo, Pinsky, Ilana, Sanches, Marcos, Zaleski, Marcos, \& Caetano, Raul. (2010). Padrão de uso de álcool em brasileiros adultos / Alcohol use patterns among Brazilian adults. Revista Brasileira de Psiquiatria, 32(3), 231-241. 
Table 3

Related problems, alcohol abuse and dependence and their relationship with socio-demographic variables (\%)

\begin{tabular}{|c|c|c|c|c|c|c|c|}
\hline \multicolumn{2}{|c|}{ Demographic } & \multicolumn{3}{|c|}{ At least one problem } & \multicolumn{3}{|c|}{ Abuse or dependence } \\
\hline & & (\%) & (SD) & p-value* & (\%) & (SD) & p-value* \\
\hline \multirow[t]{2}{*}{ Gender } & Male & $40 \%$ & $1.8 \%$ & $<0.001$ & $19 \%$ & $1.8 \%$ & $<0.001$ \\
\hline & Female & $11 \%$ & $1.0 \%$ & & $4 \%$ & $0.7 \%$ & \\
\hline \multirow[t]{5}{*}{ Age } & $18-24$ years & $34 \%$ & $3.2 \%$ & $<0.001$ (ad; ae; be; ce) & $19 \%$ & $2.9 \%$ & $<0.001$ (ac; ad; ae; be; ce) \\
\hline & $25-34$ years & $29 \%$ & $2.1 \%$ & & $12 \%$ & $1.5 \%$ & \\
\hline & $35-44$ years & $24 \%$ & $2.3 \%$ & & $11 \%$ & $1.7 \%$ & \\
\hline & $45-59$ years & $20 \%$ & $2.2 \%$ & & $9 \%$ & $1.8 \%$ & \\
\hline & 60 years or above & $13 \%$ & $2.1 \%$ & & $4 \%$ & $1.1 \%$ & \\
\hline \multirow[t]{5}{*}{ Region } & Northern & $25 \%$ & $3.6 \%$ & 0.764 & $17 \%$ & $4.6 \%$ & 0.521 \\
\hline & Center-Western & $30 \%$ & $5.2 \%$ & & $12 \%$ & $4.6 \%$ & \\
\hline & Northeastern & $26 \%$ & $2.7 \%$ & & $12 \%$ & $2.3 \%$ & \\
\hline & Southeastern & $24 \%$ & $1.6 \%$ & & $11 \%$ & $1.3 \%$ & \\
\hline & Southern & $24 \%$ & $3.2 \%$ & & $10 \%$ & $2.4 \%$ & \\
\hline \multirow[t]{2}{*}{ Rural } & Urban & $26 \%$ & $1.3 \%$ & 0.043 & $12 \%$ & $1.1 \%$ & 0.343 \\
\hline & Rural & $19 \%$ & $2.7 \%$ & & $10 \%$ & $1.7 \%$ & \\
\hline Total & & $25 \%$ & $1.2 \%$ & & $11 \%$ & $1.0 \%$ & \\
\hline
\end{tabular}

Note: Table source is Laranjeira, Ronaldo, Pinsky, Ilana, Sanches, Marcos, Zaleski, Marcos, \& Caetano, Raul. (2010). Padrão de uso de álcool em brasileiros adultos / Alcohol use patterns among Brazilian adults. Revista Brasileira de Psiquiatria, 32(3), 231-241.

\section{Discussion}

The analyses described above show a complex picture of drinking and associated problems in Brazil. At the same time in which there is considerable abstention in the population, especially among women, there also is considerable binge drinking. The latter can be seen in 2 ways. First, there is a reasonably large proportion of the population (varying by age from $17 \%$ to $33 \%$ ) who reported usual quantities of drinking that would qualify as a binge ( 5 or more units as usual quantity). When asked specifically about binge drinking, $10 \%$ to $40 \%$ of the population, depending on age, reported an episode of binge drinking in the past 12 months. In other words, moderate drinking is not common in Brazil (Laranjeira et al., 2010).

Comparisons with other countries show that Brazil has a rate of abstention that is similar to that for men and women in the U.S., similar to that of Mexico, and higher than that for most European and Scandinavian countries(Babor et al., 2010; Caetano, Baruah, Ramisetty-Mikler, \& Ebama, 2010). Brazil also has a high consumption of alcohol among men in their middle age years (forties and fifties), with usual quantity dropping more with age than drinking frequency. In other countries, for instance, the U.S., much of the drinking occurs among men and women in their twenties, dropping quite considerably after that. An exception in the U.S. population is the Hispanic group, who also report hi- gher levels of consumption during middle age, especially among men (Caetano, 1991). Thus, higher levels of consumption in the U.S. population have been associated with a youthful lifestyle (Hilton, 1991). Among U.S. Hispanics, the freedom to drink is more associated with the maturity that comes during the middle age years (Caetano, 1989; Caetano \& Kaskutas, 1995). According to Laranjeira et al. (2010), this perhaps is a good example of the different place of alcohol in American and Latin cultures. Countries in Latin America did not have strong temperance movements, which in the U.S. promoted a negative view of alcohol that is still somewhat culturally present today. Drinking in the U.S., and especially binge drinking, is seen therefore more negatively, as a behavior that only youth but not mature men indulge in. In Latin cultures, drinking is in general more integrated with daily activities and festivities. People of all ages participate in these activities and drinking becomes not as strongly associated with age, especially among men, for whom drinking norms and attitudes are more lax and allow more drinking than for women.

Binge drinking is also fairly common in Brazil. About $40 \%$ of the men and $18 \%$ of the women reported binge drinking in the past 12 months. In the U.S., the rate among men ranges from $20 \%$ to $30 \%$ and among women it ranges from $6 \%$ to $12 \%$, depending on ethnic group (Caetano et al., 2010). However, data from the 2011 U.S. National Sur- 
vey on Drug Use and Health show rates of binge drinking among older respondents (50-54, 55-59, 60-64 years of age) that are comparable to the rates reported herein for Brazil (Substance Abuse and Mental Health Services Administration [SAMHSA], 2012). Nevertheless, the decline of binge drinking in Brazil is not as abrupt as in the U.S. and many European countries (Castro et al., 2012; Laranjeira et al., 2010). Because binge drinking is a risk factor for alcohol-related problems, the Brazilian population, both younger and middle aged, is at a greater risk for developing alcohol problems. A focus on preventing this type of drinking should therefore be a priority for public health strategies related to the prevention of alcohol-related problems in Brazil.

The rates of at least one alcohol problem and alcohol use disorders in Table 3 are similar to those in previous household studies in Brazil (Carlini et al., 2007; Galduroz and Carlini, 2007). These rates are relatively high given the high rates of abstention in Brazil. For a comparison, in the U.S. (Grant et al., 2004) for 2002, the rates were $4.7 \%$ for abuse and $3.8 \%$ for dependence; in Chile (Vicente, Rioseco, Saldivia, Kohn, \& Torres, 2002), the rate for dependence was $6 \%$; and in France (Lepine et al., 2005), the rate was $0.5 \%$ for abuse and $0.3 \%$ for dependence. The best explanation for the existence of high rates of alcohol use disorders in Brazil side-by-side with a high rate of abstention is the existence of a considerable proportion of drinkers who usually drink great amounts of alcohol and binge drink. In other words, in Brazil, many people do not drink, but those who drink tend to do it in a way that increases the risk of developing alcohol problems, abuse, or dependence.

In summary, drinking in Brazil is somewhat polarized, with a relatively high rate of abstention but also a high rate of heavier drinking, such as binge drinking. As in many other parts of the world, men drink more than women and the younger drink more than those who are older. Because those who drink seem to drink usually a high number of drinks, the risk for alcohol problems is high, and so is the prevalence of alcohol use disorders.

\section{Acknowledgments}

This work was funded by the Brazilian federal government's Conselho Nacional de Pesquisas (CNPq) and by the state of Sao Paulo Fundação de Apoio a Pesquisa do Estado de SÃo Paulo (FAPESP).

\section{Conflicts of interest}

No conflicts to declare.

\section{Source and permissions for tables}

The tables presented here are taken from the following publication and are used with permission granted on Au- gust 8, 2013 by Renata Kieling from the Editorial Office of the journal Revista Brasileira de Psiquiatria.

Laranjeira, Ronaldo, Pinsky, Ilana, Sanches, Marcos, Zaleski, Marcos, \& Caetano, Raul. (2010). Padrão de uso de álcool em brasileiros adultos / Alcohol use patterns among Brazilian adults. Revista Brasileira de Psiquiatria, 32(3), 231241.

\section{References}

Babor, T. F., \& Caetano, R. (2005). Evidence-based alcohol policy in the Americas: Strengths, weaknesses, and future challenges. Revista Panamericana de Salud Publica [Pan American Journal of Public Health], 18, 327-337.

Babor, T. F., Caetano, R., Casswell, S., Edwards, G., Giesbrecht, N., Graham, K., . . . Rossow, I. (2003). Alcohol: No Ordinary Commodity: Research and Public Policy. Oxford, New York: Oxford University Press. doi: 10.1046/j.13600443.2003.00504.x

Babor, T. F., Caetano, R., Casswell, S., Edwards, G., Giesbrecht, N., Graham, K., . . Homel, R. (2010). Alcohol: No Ordinary Commodity: Research and Public Policy (2nd ed.). Oxford: Oxford University Press. doi: 10.1111/j.13600443.2010.02945.x

Caetano, R. (1989). Drinking patterns and alcohol problems in a national sample of U.S. Hispanics. In D. L. Spiegler, D. A. Tate, S. S. Aitken \& C. M. Christian (Eds.), Alcohol Use Among U.S. Ethnic Minorities (pp. 147162). Washington, D.C.: U.S. Government Printing Office.

Caetano, R. (1991). Findings from the 1984 National Survey of Alcohol Use among U.S. Hispanics. In W. B. Clark \& M. E. Hilton (Eds.), Alcohol in America: Drinking Practices and Problems (pp. 293-308). Albany, NY: State University of New York Press.

Caetano, R., Baruah, J., Ramisetty-Mikler, S., \& Ebama, M. S. (2010). Sociodemographic predictors of pattern and volume of alcohol consumption across Hispanics, Blacks, and Whites: 10-year trend (1992-2002). Alcoholism: Clinical and Experimental Research, 34, 1782-1792. doi: 10.1111/j.1530-0277.2010.01265.x.

Caetano, R., \& Kaskutas, L. A. (1995). Changes in drinking patterns among Whites, Blacks and Hispanics: 19841992. Journal of Studies on Alcohol, 56, 558-565.

Caetano, R., \& Laranjeira, R. (2006). A 'perfect storm' in developing countries: economic growth and the alcohol industry. Addiction, 101, 149-152. doi: 10.1111/j.13600443.2006.01334.x

Caetano, R., Ramisetty-Mikler, S., \& Rodriguez, L. A. (2009). The Hispanic Americans Baseline Alcohol Survey (HABLAS): The association between birthplace, acculturation and alcohol abuse and dependence across Hispanic national groups. Drug and Alcohol Dependence, 99, 215-221. doi: 10.1016/j.addbeh.2012.04.015. 
Carlini, E. A., Galduróz, J. C., Noto, A. R., Fonseca, A. M., Carlini, C. M., Oliveira, L. G., . . Sanchez, Z. M. (2007) II Levantamento domiciliar sobre o uso de drogas psicotrópicas no Brasil - 2005 (pp.468). São Paulo: Cebrid - Centro Brasileiro de Informações sobre Drogas Psicotrópicas - Departamento de Psicobiologia da Escola Paulista de Medicina e SENAD - Secretaria Nacional Antidrogas, Presidência da República, Gabinete de Segurança Nacional.

Capriglione, M. J., Monteiro, M. G., \& Masur, J. (1985). Aplicaçäo do questionario CAGE para detecçäo da síndrome de dependência do álcool em 700 adultos na cidade de Säo Paulo / Application of CAGE questionnaire for detection of alcohol dependence syndrome in 700 adults in the city of Säo Paulo Revista da Associação Brasileira de Psiquiatria, 7, 50-53.

Castro, D. S., Sanchez, Z. M., Zaleski, M., Alves, H. N., Pinsky, I., Caetano, R., \& Laranjeira, R. R.. (2012). Sociodemographic characteristics associated with binge drinking among Brazilians. Drug and Alcohol Dependence, 126, 272-276.

Galduróz, J. C., \& Carlini, E. (2007). Use of alcohol among the inhabitants of the 107 largest cities in Brazil-2001. Brazilian Journal of Medical and Biological Research, 40, 367-375. doi: 10.1016/j.drugalcdep.2012.05.017.

Galduróz, J., Noto, A. R., Nappo, S. A., \& Carlini, E. (2003a). Comparações dos resultados de dois levantamentos domiciliares sobre o uso de drogas psicotrópicas no estado de São Paulo nos anos de 1999 e 2001 / Comparisons of the results of two houshold surveys on drug abuse in the state of San Paulo in the years 1999 and 2001. Jornal Brasileiro de Psiquiatria, 52, 43-51.

Galduróz, J., Noto, A. R., Nappo, S. A., \& Carlini, E.. (2003b). First household survey on drug abuse in São Paulo, Brazil, 1999: principal findings. Sao Paulo Medical Journal, 121, 231-237.

Grant, B. F., Dawson, D. A., Stinson, F. S., Chou, S. P., Dufour, M. C., \& Pickering, R. P. (2004). The 12-month prevalence and trends in DSM-IV alcohol abuse and dependence: United States, 1991-1992 and 2001-2002. Drug and Alcohol Dependence, 74, 223-234.

Hilton, M. E. (1991). The demographic distribution of drinking patterns in 1984. In W. B. Clark \& M. Hilton (Eds.), Alcohol in America: Drinking Practices and Problems (pp. 73-86). Albany, NY: State University of New York Press.

Kerr-Corrêa, F., Igamib, T. Z., Hirocea, V., \& Tucci, A. M.. (2007). Patterns of alcohol use between genders: A cross-cultural evaluation. Journal of Affective Disorders, 102, 265-275.

Kerr-Corrêa, F., Tucci, A. M., Hegedus, A. M., Trinca, L. A., de Oliveira, J. B., Floripes, T. M., \& Kerr, L. R.. (2008). Drinking patterns between men and women in two dis- tinct Brazilian communities. Revista Brasileira de Psiquiatria, 30, 235-242.

Laranjeira, R., Pinsky, I., Sanches, M., Zaleski, M., \& Caetano, R.. (2010). Padrão de uso de álcool em brasileiros adultos / Alcohol use patterns among Brazilian adults. Revista Brasileira de Psiquiatria, 32, 231-241.

Lepine, J. P., Gasquet, I., Kovess, V., Arbabzadeh-Bouchez, S., Negre-Pages, L., Nachbaur, G., \& Gaudin, A. F. (2005). Prevalence et comorbidite des troubles psychiatriques dans la population generale francaise: resultats de l'etude epidemiologique ESEMeD/MHEDEA 2000/ (ESEMeD) / Prevalence and comorbidity of psychiatric disorders in the French general population. L'Encephale, 31, 182-194.

Ministério da Saúde. (2002). Dispõe sobre a constituição dos Centros de Atenção Psicossocial, 336 C.F.R.

Ministério da Saúde. (2003). A Política do Ministério da Saúde para atenção integral a usuários de álcool e outras drogas. In Coordenação Nacional de DST e AIDS, Secretaria Executiva (Ed.). Brasília: Ministério da Saúde.

Moreira, L. B., Fuchs, F. D., Moraes, R. S., Bredemeier, M., Cardozo, S., Fuchs, S. C., \& Victora, C. G. (1996). Alcoholic beverage consumption and associated factors in Porto Alegre, a southern Brazilian city: A population-based survey. Journal of Studies on Alcohol, 57, 253-259.

Room, R., Jernigan, D., Carlini-Marlatt, B., Gureje, O., Mäkelä, K., Marshall, M., . . Saxena, S. (2002). Alcohol and the Developing World: A Public Health Perspective. Helsinki: Hakapaino Oy.

Silveira, C. M., Wang, Y. P., Andrade, A. G., \& Andrade, L. H. (2007). Heavy episodic drinking in the São Paulo epidemiologic catchment area study in Brazil: Gender and sociodemographic correlates. Journal of Studies on Alcohol E Drugs, 68, 18-27.

Substance Abuse and Mental Health Services Administration [SAMHSA]. (2012). Results from the 2011 National Survey on Drug Use and Health: Summary of National Findings. (NSDUH Series H-44, HHS Publication No. (SMA) 12-4713). Rockville, MD: Substance Abuse and Mental Health Services Administration, Retrieved from http:/ / www.samhsa.gov/data/NSDUH/2k11Results / NSDUHresults2011.htm.

Vicente, B., Rioseco, P., Saldivia, S., Kohn, R., \& Torres, S. (2002). Estudio chileno de prevalencia de patologia psiquiatrica (DSM-III-R/CIDI) (ECPP) / Chilean study on the prevalence of psychiatric disorders (DSM-III-R/ CIDI) (ECPP) ]. Revista Medica de Chile, 130, 527-536.

Wolle, C. C., Sanches, M., Zilberman, M. L., Caetano, R., Zaleski, M., Laranjeira, R., \& Pinsky, I. (2011). Differences in drinking patterns between men and women in Brazil. Revista Brasileira de Psiquiatria, 33, 367-373. 